\title{
The Jargon Used in Kaskus
}

\author{
I Nyoman Mayusa ${ }^{1}$, I Gede Frediyana $^{2}$ \\ Faculty of Letters, Universitas Warmadewa Denpasar-Bali, Indonesia ${ }^{1,2}$ \\ \{nyoman.mayusa@gmail.com¹, frediyana@gmail.com²
}

\begin{abstract}
This study intends to find out the kinds of jargon used in Kaskus forum. The method applied in this study is a descriptive method which the data are described qualitatively through semantic point of view. The basic theory used in this study is taken from the theory of Fromkin and Rodman in their book entitled An Introduction to Language. Based on analysis of kinds of jargon used in Kaskus, it was found that there are three kinds of jargon found in Kaskus. Furthermore, the three kinds of jargon found in Kaskus are classified into three categories. The first is jargon related user's reputation, second is related to buying and selling activities, and the last one is related to popular utterance. In conclusion, Jargon is a special language that is used in a particular field, a particular environment, and a particular situation. In Kaskus Forum, it discovered that there are 114 words considered as jargon from Kaskus.
\end{abstract}

Keywords: Jargon; Kinds of Jargon; Kaskus

\section{Introduction}

Jargon generally implies the particular language utilized by individuals in a similar work or profession. Web publicizing language incorporates the expressions "click through" and "spage views." This noun can likewise allude to language that utilizations long sentences and hard words. In Middle English, this word alluded to chattering, so its source is presumably imitative: it echoes the sound of chatter or pointless words. Kaskus is an Indonesian Internet forum that is the largest Indonesian online community. Kaskus was created on November 6, 1999, by Indonesian students Andrew Darwis, Ronald Stephanus, Ken Dean Lawadinata and Budi Sudarsono in Seattle, Washington. KASKUS was originally intended as an informal forum of Indonesian students abroad. The name "KASKUS" itself is an abbreviation of the word "KasakKusuk". This site is managed by PT Darta Media Indonesia. Kaskus has more than 6 million registered users (since the writers registered their account). Kaskus users generally come from teenagers to adults who are domiciled in Indonesia or outside Indonesia. In Kaskus forum, it can be known more closely with others throughout Indonesia people and can be connected to each other. At Kaskus forum, there is space to share information and place to conduct sale and purchase transactions. There are many unusual terms that only the members of the forum who understand them. The example of conversations found that is contained strange terms can only be understood by the members of Kaskus forum can be seen below.

For example:

Minecraftndns : Please TS give us more information about shark megalodon!, I wanted to know more information. 
Ciu Ciu : I like your post bro

Lepi Error : : who got banned?

Maling Kaskus : She is Babby20 AKA Dewi

The underlined terms above are often found and used by Kaskusers (the members of the users of Kaskus) in Kaskus forum. The words TS is the abbreviation for Thread Started. Thread Started is a thread or start of a new topic by one or more Kaskusers, and for the term Bro means Brother which is used to call male members as if they are families, while the term AKA means as known as. Those special and unique terms or word used within specific group are called Jargon, such as the words or terms used in Kaskus Forum. So, it can be said the jargon can be used to refer to the characteristic of a group, occupation, trade, etc. Jargon provides limited access for people who are not from society.

The similar study has been conducted [1] entitled "An Analysis of Jargons Used By Receptionists in Front Office At Grand Istana Rama Hotel", the finding demonstrated that 1) the linguistic types of languages utilized in front office at Grand Istana Rama Hotel are shortening, abbreviation, acronym, affixation, lexical borrowing, coinage, word and expression arrangement. 2) the significance of each linguistics structure depends on its utilization. 3) the function of every jargon were: giving specialized language and empowering in-bunch solidarity. Furthermore, another similar study has conducted [2] entitled "An Analysis of Jargon Used in Political Website", the finding demonstrated that the political language in this site can be investigated in structures were 53 words, 15 expressions, 5 shortened forms and there was no abbreviation, in the lexical implications classifications there were 58 denotative implications and 15 suggestive implications from 73 information and the elements of Political Jargon were a things to a particular gathering, to convey and signal for distinguishing proof of political group. [3] Similar study have been conducted entitled "An Analysis of Jargon Used By the Teenagers Found in Facebook", the finding demonstrated that there were 72 jargons found in Facebook. It was discovered (72) jargon utilized by the youngsters in Facebook. They were: 6 jargon found on June sixteenth, 9jargons found on June seventeenth, 13 languages found on June eighteenth, 11 jargon found on June nineteenth, 9 jargon found on June twentieth, 9 jargon found on June 21 st, 9 jargon found on June 22nd, and 6 jargon found on June 23rd. The jargon were utilized in casual circumstance. At that point, the significance of every jargon was checked by taking a gander at the setting of exchanges and discussions among Facebookers precisely the teenagers. Referring to the background and the latest related studies above, this study is going to analyze Jargon in Kaskus. Therefore, the objectives of the study is to find out the kinds of jargon found in Kaskus Forum.

\section{Method}

The data of this study are taken from the website of Kaskus forum. The data were collected through observation method. The method used in this study is descriptive method. Moreover, the data that have been collected and classified were analyzed based on the theory applied and based on the technique or procedures available. However, in doing the analysis, there are some steps were done. Firstly, find the history of Kaskus, the second, made a list of Kaskus jargon words, the third, found the definition of the jargon words by observing and interviewing the participants and the last one was classified the kinds of jargon. 


\section{Results and Discussion}

As explained previously, this study aims to find out the kinds of jargon found in Kaskus forum. In brief, based on the analysis it was found the kinds of jargon in Kaskus forum which is the meaning is classified into two, they are denotation and connotation meaning. Briefly, more explanation is described below.

\subsection{Kaskus Forum History}

KASKUS was made on November 6, 1999, by Indonesian understudies Andrew Darwis, Ronald Stephanus, Ken Dean Lawadinata and Budi Dharmawan. KASKUS was initially planned as a casual gathering of Indonesian understudies abroad. The name "KASKUS" itself is a truncation of "Kasak-Kusuk"

PC Magazine Indonesia named Kaskus in August 2005[2] just like the best website and biggest online network and in 2006, as the selection of perusers in 2006. On May 23, 2006, the administration had to change their .com area to .us, in light of the spread of the infection Brontok which was made with the point of assaulting huge locales in Indonesia. Toward the start of April 2007, KASKUS the executives added two new Dell Servers to improve KASKUS's site execution. In July 2008, KASKUS the executives chose to work the worker in Indonesia. For this reason, KASKUS purchased eight Dell PowerEdge 2950 workers and worked them through an organization of open IXP. This brought about increased admittance to KASKUS and inevitably added eight additional workers to deal with the solicitations.

In March 2008, in the wake of persuading his cousin Andrew to Expand and make an appropriate business out of KASKUS, Ken Dean Lawadinata went ahead board as accomplice and CEO. PT Darta Media Indonesia was then made as the parent organization of KASKUS, before the finish of 2008, KASKUS went on a significant extension and changes in its product offering and vision to turn into the No.1 Largest Local site in Indonesia, and got its initial 1 Million client base.

In 2011, KASKUS the board reported the extension of its business by building up a relationship of collaboration with the venture of Global Digital Prima into KASKUS, which is an auxiliary of Djarum. Furthermore, KASKUS plans to build the quantity of workers up to 250. They additionally plan on selecting up to 80 new faculty. In August 2012, Kaskus had in excess of 4,000,000 enrolled accounts. On May 26, 2012, KASKUS the executives had to change their area from .us to .co.id in view of mistakes on the Domain Name System (DNS). In 2012, KASKUS the board built up their own gathering motor authoritatively called KASKUS 2.0, called the New KASKUS by KASKUS's users.[3] When the motor arrived at a beta stage, chosen clients utilized the discussion with the motor, while non-chose clients actually utilized the vBulletin variant. Before the finish of 2012, a total transformation to KASKUS 2.0 was finished. A few strings and posts couldn't be moved to the new motor, so KASKUS the board chose to keep them available through the Bulletin adaptation of the discussion (called Old KASKUS by the clients).

2014 KASKUS had in excess of 25 million interesting clients and was a popular neighborhood site in Indonesia. On this year KASKUS additionally experienced a few changes with Ken Dean Lawadinata after his 7 years of the turnaround of KASKUS from a 1-man discussion webpage to Indonesia's driving on the web gathering, climbed to turn into the new Chairman of PT Darta Media Indonesia, with Martin Hartono expecting the everyday activity as the new CEO. Andrew Darwis additionally moved from his office of CTO to turn into the Chief Community Officer for KASKUS. 
In 2015, KASKUS story is underway to be adjusted to turn into a significant Cinema film with the codename "Ken and Andrew, The film".

\subsection{The Jargon Used by Kaskus Member and Their Meanings}

In order to collect jargon used in Kaskus, it was searched into the forum and found many different lists containing Kaskus jargon. All of the lists almost contain similar vocabulary, however, the goal that would like to attain was to find out the most complete list that can give the valid data. After searching for some periods, there was one thread mentioning that there was a dictionary made by a Kaskus member.

The data from the dictionary could not be considered as a complete one because of several reasons. One of the reasons is the dictionary itself does not include the latest jargon tending to be used today, for example, a s a p, etc. The other reason is that it is assumed that the dictionary contains all vocabulary, but only some of them are considered as jargon. As a result, there was only fetched some of them and combined with the data taken when observing Kaskus forum and interviewing some members. There were 114 jargons on Kaskus. It does not include new vocabulary.

For examples:

$B T W$ where are you from dude?

Page one gan! ... lol ... what's up big boys!

In example (1), $B T W$ is mean By The Way this phrase is often used by young people in chat. In the forum Kaskus, this word is often used when one member discusses other things or ask other things. At that time the word BTW used to impress other members do not ask the same thing.

In example (2), gan mean short for juragan, call fellow member KASKUS. This word is often used to call other members on forums. This word is used on the internet forums, one of them is Kaskus forum. The word gan this is usually used to other members so that they are not tired to type a user name that is often the name used is very difficult and can speed up the writing.

\section{a) Jargon Related to User's Reputations}

The words of jargon in this section relates to the user's status and reputation. Kaskus is a forum site that is designed to make the members share their knowledge among the other members. Therefore, reward and penalty points imposed. The point's reputation can also help members are good or bad. Additionally, it provides members with good information when making multiple transactions at FJF (trading forum). That is the reason why some of the jargon words, such as cendol and red brick were created.

However, it is not just about reputation points, but this section also concentrates on the words jargon associated with the user's picture and status. For example, members can donate money to get Kaskus, donor status can access more features for free members (therefore, Donuts jargon word began to be used), and member of the ad /her blog, websites, and products but do not consider whether the rule can be considered as a spammer.

For example:

Can I get my account back, because my first id will taken to id banned?

I'll give you cendol, I love your post 
In example (1), id banned is statues of the user name or ID member which is not allowed to access Kaskus because the member does not comply with the Kaskus rule. Usually, moderator or admin has this authority to ban some IDs from Kaskus.

In example (2), cendol is a condition when a member gets a good reputation point because he/she does some good actions, for example, a buyer gives good service to a seller so the seller is satisfied and gives cendol to the buyer. Cendol is the name of Indonesian drink. It is named as Cendol because the colour of the bar is green the same as cendol colour.

\section{b) Jargon Related to Selling and Buying Activities}

Kaskus is an internet website forum which has many features. Buying and selling is one of them. Therefore, this section is intended to list the jargon which tends to be used in buying and selling forum. Because the jargons are usually used in buying and selling forum, no wonder if most of them related to negotiation, price, and money.

For example:

$C t r l+D$ gan

Hey minecraftndns you have bump above 3x daily

If you make any wrong such us:

Spam

Junk post/thread

And other who violate the rule FJB

In example (1), Ctrl $+d$ is a keyboard command done by pressing ctrl key $+d$ key. In Kaskus forum, ctrl $+\mathrm{D}$ is mean bookmark feature which can be accessed after doing $c t r l+d$ command in the chrome web browser.

In example (2), Bump means Kaskus uses bulletin V6 system which allows a tread to emerge in the first sequence from page one if someone replies a comment to the tread. The action related to this action is called bump.

\section{c) Jargon Related to Popular Utterance}

Besides jargons which are classified in the previous sections, there are some jargons related to popular utterances. They tend to be used in Kaskus forum. Most of them are quite funny to be heard but somehow they are quite popular because of the consistency to appear on many occasions, the jargons are becoming the trademark of Kaskus. Jargon in this section almost does not relate to buying and selling activities. They are usually used in other subforums, for example music, games, and movie.

For example:

Can I find $a k t b$ for XL in my city?

wow i feel like dejavu when seen you!

In example (1), $A K T B$ is a commercial feature which is provided for any member who wants to donate some money. The benefit is the member can access Kaskus fast than usual there is no banner advertisement. It was found the meaning of $A K T B$ after interviewing the Kaskus member.

In example (2), the word dejavu is derived from déjà vu which is borrowed from French. In Kaskus, the meaning is different from the literal meaning which is "the feeling that you have previously experienced something which is happening to you now". In Kaskus, it uses to replace repost word. It means that a thread has the same content with another tread. 


\subsection{The Jargon with Connotation Meaning}

In Kaskus forum, their jargon has many connotation meaning. Red bar change into red brick, and so on. There is some Jargon that has connotation meaning.

For example:

Why is this thread so annoying to many people? but the purpose of this post is to make us realize how the future impact for humans

How much supernet for this wifi?

To remove red brick you just need to make your reputation better again, suppose you sell goods with the right price and no intention to deceive other members

In example (1), thread has connotation meaning because the additional meaning that words a word or phrase has beyond its central meaning. Thread is a topic intended to invite other members to just read or maybe reply to some comments related to the topic. The meaning of thread is different from the literal meaning.

In example (2), supernet has connotation meaning. Because supernet means that the price is fixed and cannot be negotiated anymore. In Kaskus, a buyer is always asked the supernet by PM (personal message). The member will catch different meaning when he/she just considers literal meaning.

In example (3), red brick has connotation meaning because of the additional meaning that word or phrase has beyond its central meaning. As we know in Kaskus, red brick is a condition when member has a bad reputation because he/she does some wrongdoings. A bad reputation is accumulative, it means that how many bars appear on the status represents how many wrongdoings he/she has done. It is named as Red Brick because the colour of the bar is red the same as brick colour. This is shown people's emotions and attitude towards what the words or phrase refers to something.

\subsection{The Jargon with Denotation Meaning}

Jargon on Kaskus forums besides having a connotation, most of the jargon in Kaskus forum also has the meaning of denotation.

For example:

I want to report a scam that befell me for Reseller in FJB forum, the goods I bought are not

like the description in

WTB computer screen with samsung brand, price less than 2 million rupiahs. Preferably can $C O D$ in Mataram area, which seriously can directly contact me or can give under comment column. payment is preferred using rekber from a trusted place. thank you

In example (1), Reseller has a denotation meaning because the words are real meaning not a word is deliberately created to replace the actual meaning. Reseller means people who sell the stuff that they get from the supplier. A seller gives some opportunities to other members by sharing their profits for the members who can sell their items. This way is intended to spread the network of sellers when selling their items.

In example (2), $W T B$ and $C O D$ have denotation meaning because the words are real meaning not a word is deliberately created to replace the actual meaning. WTB is an abbreviation from want to buy. Bringing WTB to the title is purposed to emphasize that the thread starter wants to buy some items that the specifications can be viewed inside the thread and $C O D$ was taken from Cash on Delivery, it is used to say that the payment has to be done after buyer and seller meet each other directly (offline). This method of payment happens to 
anticipate dissatisfaction between member and seller. The meaning COD is obtained after I interviewed the Kaskus member.

\section{Conclusions}

Grounded by the analysis of the data, thus it can be drawn some conclusion. Jargon is the special expression or language that is used in a particular field, a particular environment, and the particular situation. In Kaskus Forum, it was discovered that there are 114 words considered as jargon from Kaskus, but in this study, there are only 31 words are explained from Kaskus jargon. For examples: red brick, cendols, aktb, wtb, and etc. There are the functions of jargon: jargon functions to outline the boundaries of occupation, jargon allows conversation to flow more efficiently, jargon generates feeling of belonging, and jargon generates and sustains identity. The jargon words are classified according to three categories. The first is jargon related user's reputation, second is related to buying and selling activities, and the last one is related to popular utterance. All of the jargon words are classified according to the definition of jargon. After classifying the jargon words, it was carried out some analyses related to the semantic meaning. Some of the Kaskus jargon has Connotation and denotation meaning.

\section{References}

[1] K. T. D. Pridipta, “An Analysis of Jargons Used By Receptionists in Front Office At Grand Istana Rama Hotel,” Jurnal Pendidikan Bahasa Inggris Undiksha, vol. 5, no. 2, p. $9,2017$.

[2] D. Syafitri and M. Ikhsan, "An Analysis of Jargon Used in Political Website," Linguistic, English Education and Art (LEEA) Journal, vol. 2, no. 2, pp. 151-172, 2019.

[3] D. Asrifah, "An Analysis of Jargon Used By the Teenagers Found in Facebook," University of Muhammadiyah Malang, 2012. 